\title{
Thermal oxidation of sputtered nickel nano-film as hole transport layer for high performance perovskite solar cells
}

\author{
Mustafa Aboulsaad ${ }^{1,2}$ (D) Ayman El Tahan ${ }^{3} \cdot$ Moataz Soliman $^{2} \cdot$ Said El-Sheikh $^{4} \cdot$ Shaker Ebrahim $^{2}$
}

Received: 17 July 2019 / Accepted: 3 October 2019 / Published online: 19 October 2019

(C) The Author(s) 2019

\begin{abstract}
The effect of rapid oxidation temperature on the sputtered nickel (Ni) films to act as a hole transport layer (HTL) for perovskite solar cell (PSCs) was investigated. A nano-sputtered Ni film with a thickness about $100 \mathrm{~nm}$ was oxidized at a range of different oxidation temperatures between 350 and $650{ }^{\circ} \mathrm{C}$ to work as HTL in an inverted p-i-n configuration. DC Hall measurement in van der Pauw configuration and photoluminescence spectroscopy were used to measure the charge's mobility and extraction of nickel oxide $(\mathrm{NiO})$ films. The behaviour of the carrier concentration measurements of $\mathrm{NiO}$ layers at different oxidation temperatures showed that the $\mathrm{Ni}$ layer oxidized at $450{ }^{\circ} \mathrm{C}$ had the highest carrier concentration among the other samples. The performance measurements of the fabricated PSCs showed that the nickel oxide hole-transporting layer which has been oxidized at the optimum oxidation temperature of $450^{\circ} \mathrm{C}$ has the highest power conversion efficiency (PCE) of $12.05 \%$. Moreover, the characteristic parameters of the optimum cell such as the open-circuit voltage $\left(\mathrm{V}_{\mathrm{OC}}\right)$, short-circuit current density $\left(\mathrm{J}_{\mathrm{SC}}\right.$ ) and fill factor $(\mathrm{FF})$ were $0.92 \mathrm{~V}, 19.80 \mathrm{~mA} / \mathrm{cm}^{2}$ and 0.331 , respectively.
\end{abstract}

\section{Introduction}

Perovskite materials can change their properties over the main three classifications of materials; conductor, insulator and semiconductor. They are denoted by $\mathrm{ABX}_{3}$ structure as three different materials that can be combined with certain structure [1]. Metal halide perovskites as dyes under illumination can generate and transport of charge carriers in the perovskite solar cells (PSCs) [1]. Methylammonium lead triiodide $\left(\mathrm{CH}_{3} \mathrm{NH}_{3} \mathrm{PbI}_{3}\right)$ perovskite material started to be booming in the field of energy harvesting due to its excellent optoelectrical properties where it has a direct bandgap, wide

Electronic supplementary material The online version of this article (https://doi.org/10.1007/s10854-019-02345-2) contains supplementary material, which is available to authorized users.

Mustafa Aboulsaad

mustafa@uef.fi; mostafa.aboulsaad@alexu.edu.eg

Ayman El Tahan

amoussa73@yahoo.com

Moataz Soliman

msoliman@alexu.edu.eg

Said El-Sheikh

saidelsheikh@cmrdi.sci.eg

Shaker Ebrahim

shaker.ebrahim@alexu.edu.eg range of solar spectrum absorption [2], high an absorption coefficient of $1.5 \times 10^{4} \mathrm{~cm}^{-1}$ at $550 \mathrm{~nm}$ [3], high charge carrier mobility of $66 \mathrm{~cm}^{-2} \mathrm{~V} \mathrm{~s}$, small exciton binding energy with less than $10 \mathrm{meV}$ [4], and long electron-hole diffusion length with up to $1 \mu \mathrm{m}[5]$.

Due to the instability of the liquid electrolyte in solar cells, there are attempts to replace the liquid electrolyte with a solid material or quasi-solid material as was done in the dye-sensitized solar cells [6]. In perovskite solar cells, a hole transporting layer (HTL) is used instead of liquid electrolyte to extract hole carriers and transport them into the electrode $[7,8]$. The commonly HTL is $2,2^{\prime}, 7,7^{\prime}$-tetrakis(N,N-di-4-methoxyphenylamino)-9,9'-spirobifluorene (spiro-OMeTAD) which was reported over 2 decades [9, 10]. On the other hand, there are different materials from

1 Institute of Photonics, Department of Physics and Mathematics, University of Eastern Finland, Joensuu Campus, 80100 Joensuu, Finland

2 Department of Materials Science, Institute of Graduate Studies and Research, University of Alexandria, 163 Horreya Avenue, El-Shatby, Alexandria 21526, Egypt

3 Department of Physics, Faculty of Science, University of Tanta, Qism 2, Gharbia Governorate, Tanta 31527, Egypt

4 Department of Nanomaterials and Nanotechnology, Central Metallurgical Research and Development Institute, Cairo 11421, Egypt 
inorganic, organic as well as hybrid materials to employ for extracting holes from perovskite.

In the current work, nickel oxide $(\mathrm{NiO})$ is applied as HTL in an inverted configuration of $\mathrm{CH}_{3} \mathrm{NH}_{3} \mathrm{PbI}_{3}$ based PSCs. $\mathrm{NiO}$ is a p-type material with wide bandgap energies, which has been used as HTL in organic and inorganic optoelectronic devices [11]. Chen et al. constructed an inverted planar configuration of perovskite solar cell that achieved power conversion efficiency (PCE) over 16\% when they used a composite of $\mathrm{Li} \mathrm{Mg} \mathrm{Ni} \mathrm{O} \mathrm{[12].} \mathrm{There} \mathrm{are} \mathrm{different}$ processes to prepare and deposit $\mathrm{NiO}$ such as solution-processed [13], evaporation [14], spray pyrolysis or sputtering [15]. Furthermore, there are several working temperatures of $\mathrm{NiO}$ or $\mathrm{Ni}$ for annealing or oxidation processes ranging between 275 and $550{ }^{\circ} \mathrm{C}$ [11]. Hence, choosing the deposition method, working temperature, or the preparation technique is depending on the application of the work. Although the solution-processed of $\mathrm{NiO}$ is a cost-effective technique, there is a lack of the uniformity of the film at high temperature. Lai et al. [16] studied the effect of different oxidation temperatures of $\mathrm{NiO}$ deposited onto indium tin oxide (ITO) sheets on the performance of PSCs and they reported that the maximum efficiency at $450{ }^{\circ} \mathrm{C}$ was $7.75 \%$. However, ITO substrate is instable at high oxidation temperatures [17], and the resistivity of the sheets is increased with increasing the temperature [18] which may affect the result of the cell performance.

The aim of this work is to homogenize a physical sputter of Ni layers which act as HTL in PSCs by oxidizing them at different temperatures. Furthermore, the effect of the oxidation temperatures ranging between 350 and $650{ }^{\circ} \mathrm{C}$ of $\mathrm{Ni}$ films formed onto the top of fluorine tin oxide (FTO) sheets and their influence on the performance of the perovskite solar cells were studied and evaluated.

\section{Experimental work}

\subsection{Materials}

Hydroiodic acid (57 wt\% in ethanol), methylamine (CH3NH2) (40 wt\% in aqueous solution), dimethyl sulfoxide (DMSO) (extra pure $>99 \%$ ), and dimethylformamide (DMF) (extra pure > 99\%) were purchased from Across company. Lead iodide (99.998\%) and toluene were purchased from Alfa Aesar. Phenyl-C61-butyric acid methyl ester (PCBM) (99\%) and diethyl ether (99\%) were purchased from Ossila and Fisher scientific. Lithium fluoride (99\%) was obtained from Sigma Aldrich. Ni target was fabricated in a local company with purity $(99.8 \%)$. Finally, fluorine tin oxide (FTO) with a sheet resistance of $15 \Omega / \square$ used as a photoelectrode for the perovskite solar cell. All stated materials have been used as received without further purification.

\subsection{Preparation of methylammonium iodide}

Methylammonium iodide $\left(\mathrm{CH}_{3} \mathrm{NH}_{3} \mathrm{I}\right)$ was synthesized using the procedure reported by Wang et al. [19]. $30 \mathrm{~mL}$ of $\mathrm{HI}$ was reacted dropwise with $27.86 \mathrm{~mL}$ of $\mathrm{CH}_{3} \mathrm{NH}_{2}$ in a $250 \mathrm{~mL}$ round bottom flask for $2 \mathrm{~h}$ with maintaining the reaction temperature at $0{ }^{\circ} \mathrm{C}$ with continuous stirring. Using rotary evaporator, the mixture was maintained at $50{ }^{\circ} \mathrm{C}$ to evaporate the solvent and white-yellowish precipitation of $\mathrm{CH}_{3} \mathrm{NH}_{3} \mathrm{I}$ was formed. Then, the precipitated powder was collected, washed with ethanol and diethyl ether three times for further purification by stirring the solution for $30 \mathrm{~min}$ for each wash, then dried under vacuum at $60{ }^{\circ} \mathrm{C}$ overnight. The dried powder was stored inside a glove box for further usage.

\subsection{Preparation of methylammonium lead triiodide}

Methylammonium lead triiodide $\left(\mathrm{CH}_{3} \mathrm{NH}_{3} \mathrm{PbI}_{3}\right)$ was synthesized according to the reported procedures of Maria Konstantakou et al. with some modification in the ratios [20]. $\mathrm{CH}_{3} \mathrm{NH}_{3} \mathrm{I}$ was mixed with $\mathrm{PbI}_{2}$ with 1:1 molar ratio in mixed solvents of DMSO: DMF with 0.7:0.3 $\mathrm{mL} / \mathrm{mL}$. The final solution was stirred overnight at room temperature.

\subsection{Device fabrication}

FTO-coated glass substrates were cleaned by ultrasonication using distilled water, acetone, ethanol and isopropanol for $15 \mathrm{~min}$ for each solvent. These substrates were dried under nitrogen gas to remove any solvent residuals [21]. A $100 \mathrm{~nm}$ thick Ni was sputtered using DC sputtering (Hummer 8.1) at $70 \mathrm{~W}$ for 5 min onto the surface of cleaned FTO. Then, the sputtered layers were oxidized rapidly at $350,450,550$ and $650{ }^{\circ} \mathrm{C}$ in a muffle furnace. The process was carried out by adjusting the controller of the furnace to reach the desired temperature for each sample in $60 \mathrm{~min}$. Once the desired temperature was reached, the annealing time was maintained for $90 \mathrm{~min}$ to allow oxidation. Before deposition of perovskite material, $\mathrm{NiO}$ layers were heated at $40{ }^{\circ} \mathrm{C}$ to enhance the activity of the surface to get a well-deposited layer of perovskite. In glove box, $\mathrm{CH}_{3} \mathrm{NH}_{3} \mathrm{PbI}_{3}$ was deposited on $\mathrm{NiO}$ surface through one-step spin-coating deposition technique for $40 \mathrm{~s}$ divided as follow; the first $10 \mathrm{~s}$ the layer was deposited at $1000 \mathrm{rpm}$ to allow a uniform distribution of the solution on the surface, after that, the spinner was raised at $4000 \mathrm{rpm}$ for the remaining $30 \mathrm{~s}$. For enhancing the surface and crystal structure of perovskite layer, a $700 \mu \mathrm{L}$ toluene was vigorously added after $30 \mathrm{~s}$ from the whole time to allow the quenching of the grain size of the active layer to occur [20,22]. The role of the toluene is to add nonsolvent that does not dissolve perovskite material but is miscible 
with DMSO and DMF to remove the residual solvents that do not evaporate $[20,22]$. The final layers were annealed on a hotplate at $120{ }^{\circ} \mathrm{C}$ for $25 \mathrm{~min}$. Then, a filtered prepared solution of PCBM (20 mg PCBM/1 mL chlorobenzene) was

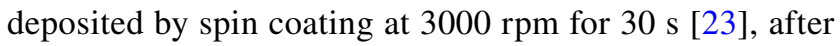
that, the layers were annealed for $10 \mathrm{~min}$ at $60{ }^{\circ} \mathrm{C}$.

Finally, using thermal evaporator, a very thin layer from $\mathrm{LiF}$ was deposited on the surface of the PCBM layer, then, a silver thin film was deposited as a counter electrode. The role of using LiF with PCBM is to avoid the hot metal particles from penetrating the PCBM layer causing direct contact between the active layer and the counter electrode [24]. Figure 1 shows the configuration of the fabricated PSCs layers in this study and its energy diagram. The valence band (VB) of $\mathrm{NiO}$ is properly positioned for extracting photoexcited holes from the valence band of $\mathrm{CH}_{3} \mathrm{NH}_{3} \mathrm{PbI}_{3}$ active layer. It is worth noting the effect of the hole selective contact as well as the position of its valence band on the performance of the cell. The existence of HTL influences on the series resistance $\left(R_{S}\right)$ of the device where the $R_{S}$ decreases in the devices with HTL while it contributes to the whole resistance significantly in the cells without HTL [25]. In addition, the devices with HTL exhibits high $\mathrm{V}_{\mathrm{OC}}$ and low recombination losses, which enhance the collected power from the device [25]. Effect of the position of the hole transporting layer valence band on the performance of carrier's extraction is relevant due to the other factors that affect the carrier extraction process such as the applied voltage and the selective contact resistance $\left(\mathrm{R}_{\mathrm{SC}}\right)$ itself $[25,26]$. However, in terms of absolute values, the closeness of the position of VB of the HTL to the position of the VB of the active layer promotes the hole relaxation between their valence bands [26].

\subsection{Characterization techniques of NiO thin films}

\subsubsection{Ultraviolet-visible (UV-Vis) spectroscopy}

The transmission and absorption spectra of $\mathrm{NiO}$ thin films were obtained in the range of $400-900 \mathrm{~nm}$ using UV-Vis spectrophotometer (Evolution 600 double beam scanning spectrophotometer, Thermo Scientific, USA).

\subsubsection{Photoluminescence (PL)}

Photoluminescence is the re-emission of light after absorption of incident photons by semiconductor materials with energy greater than bandgap energy $(\mathrm{Eg})$. The excited carriers in higher energy levels relax to the available level in ground state by emitting a photon. Photoluminescence measurements were recorded for the active layer at an excitation wavelength of $440 \mathrm{~nm}$. PL measurements were carried out at room temperature with a fluorescence spectrophotometer (Perkin Elmer LS-55).

\subsubsection{X-ray diffraction (XRD)}

X-ray diffraction scans were obtained using X-ray 7000 Shimadzu (Japan) at room temperature. The Bragge angle has (20) the range from 10 to 80 degree to study the crystallinity of the prepared films. The $\mathrm{X}$-ray source is a $\mathrm{Cu}$ target generated at $30 \mathrm{kV}$ and $30 \mathrm{~mA}$ with a scan speed of $4 \mathrm{deg} / \mathrm{min}$.

\subsubsection{Scanning electron microscopy (SEM)}

The surface of different films was investigated using scanning electron microscopy (SEM "JEOL JSM-6360 LA", Japan) to study morphology and the homogeneity of the surface. Thin films of gold were sputtered onto the samples to get charge-free surfaces.

\subsubsection{Hall measurements}

HMS-5000 Hall Effect Measurement System Ecopia (Korea) is used to measure the conductivity, carrier mobility and carrier concentration of prepared $\mathrm{NiO}$ thin films.
Fig. 1 Schematic diagram of the fabricated PSCs based on the inverted planar configuration of $\mathrm{FTO} / \mathrm{NiO} / \mathrm{CH}_{3} \mathrm{NH}_{3} \mathrm{PbI}_{3} / \mathrm{PCBM} /$ $\mathrm{LiF} / \mathrm{Ag}$ and the energy diagram of $\mathrm{p}-\mathrm{i}-\mathrm{n}$ perovskite solar cell using nickel oxide as hole extraction layer [27-29]
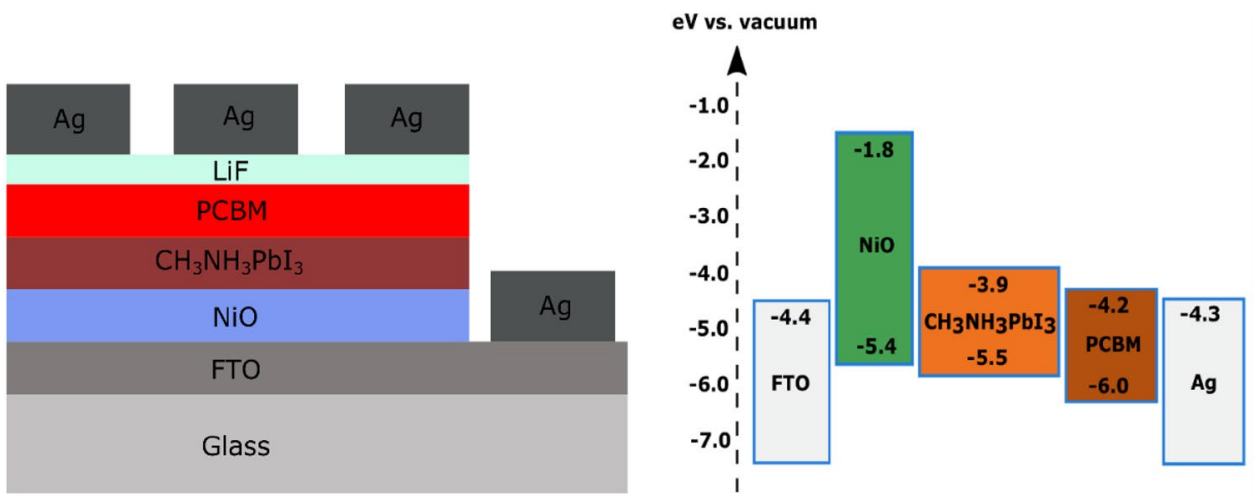


\subsection{Performance measurement of perovskite photovoltaic cell}

The current-voltage characteristics were performed for the fabricated photovoltaic cells under both dark and illumination conditions using computerized KEITHLEY series 2635A system source meter instruments controlled by TSP Express Software. The measurements have been performed using a Xenon lamp, which has been calibrated using standard PV cell.

\section{Results and discussion}

\subsection{Optical properties of NiO}

Due to the inverted planar configuration of the device, highly transmittance of HTM is needed to allow highly absorption spectrum for the perovskite layer. Hence, the transparency percentage ( $\mathrm{T} \%)$ of the $\mathrm{NiO}$ layer has been measured as a function of oxidation temperature. As shown in Fig. 2, the transmittance degree of 450 and $350{ }^{\circ} \mathrm{C}$ is about $80 \%$ between wavelength ranges $500-600 \mathrm{~nm}$, while for 550 and $650{ }^{\circ} \mathrm{C}$ the transmittance is decreased by $\sim 10 \%$ for the same interval of wavelength. The average transmittance spectra values over the whole wavelength range for $350,450,550$ and $650{ }^{\circ} \mathrm{C}$ are $80.25,75.62,71.56$ and $68.26 \%$, respectively. To understand the behaviour of transmittance of the film, it is required to interrupt the relationship between the wavelength-dependent refractive index $n(\lambda)$ with the transmittance of the film. The relation has been proposed by

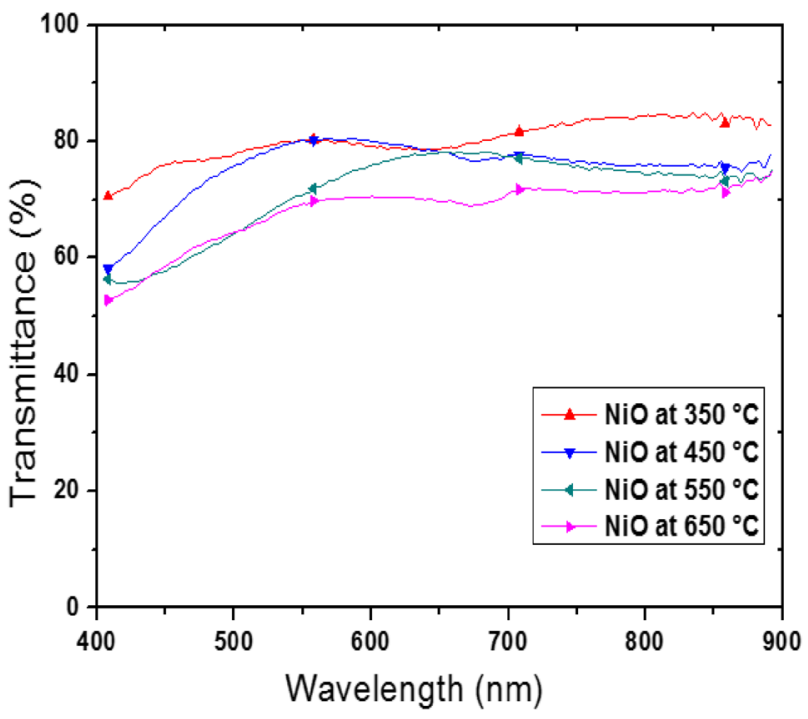

Fig. 2 Transmittance spectra of $\mathrm{NiO}$ layers oxidized at different temperatures
Sreemany et al. to calculate $n(\lambda)$ with respect to T \% [30]. Equation 1 estimates the value of $n(\lambda)$ :

$\mathrm{n}(\lambda)=\sqrt{\mathrm{n}_{\mathrm{o}} \mathrm{n}_{2}}\left[\frac{1+\sqrt{1-\mathrm{T}(\lambda)}}{\mathrm{T}(\lambda)}\right]$,

where $\mathrm{n}_{\mathrm{o}}$ and $\mathrm{n}_{2}$ are the refractive index of air and FTO substrate, respectively. From the equation, there is an inverse proportional relation between the wavelength-dependent refractive index of the film and the transmittance value.

In addition, the measurements of the oxidation temperature-dependent bandgap energy have been studied. There is a fluctuation of the bandgap energy as the oxidation temperature increases, where the measurements confirmed the bandgap energy behaviour as reported by Venter et al. [31]. The oxidized nickel film at $450{ }^{\circ} \mathrm{C}$ recorded the highest bandgap energy of $3.65 \mathrm{eV}$ while the bandgap energies of nickel films oxidized at 350,550 and $650{ }^{\circ} \mathrm{C}$ are $3.46,3.48$ and $3.59 \mathrm{eV}$, respectively. Figure 3 shows the optical absorbance spectra of oxidized nickel films at different temperatures as well as the bandgap energy of $\mathrm{NiO}$ layers using Tauc method [32].

The charge transfer process between the perovskite and HTL is also dominated by the perovskite/HTL interface, which can be evaluated by the steady-state photoluminescence (PL) measurement as displayed in Fig. 4. The measurement has been done under excitation wavelength at $440 \mathrm{~nm}$ for the stack of glass/perovskite and glass/NiO/ perovskite. As shown in Fig. 4, there is a radiative recombination peak at $738 \mathrm{~nm}$ for the perovskite layer. Apparently, $\mathrm{NiO}$ shows a significant PL quenching, indicating holes extraction and transfer at $\mathrm{NiO} /$ perovskite interface effectively. To understand the behaviour of $\mathrm{NiO}$ film that has been oxidized at $450{ }^{\circ} \mathrm{C}$ and its apparent effective extraction of holes from perovskite film, we need to consider the study which has been carried by S. Hietzschold et al. about the effect of annealing temperature on the work function of NiO films [33]. They have shown that the work function of $\mathrm{NiO}$ films at $400{ }^{\circ} \mathrm{C}$ was less than the work function at $325^{\circ} \mathrm{C}$, which promote the carrier extraction of $\mathrm{NiO}$ film. As a result, according to the calculated bandgap energies in this work, the maximum bandgap energy was for the oxidized nickel film at $450{ }^{\circ} \mathrm{C}$, which has the lowest work function, and this allows extract carriers greater than the one with high work function.

\subsection{Crystallinity of NiO layers}

The heat treatment process on metals, which is characterized by a large number of very small metal crystals interlocked together cause changes in the mechanical properties and crystal structures of these metals [34]. At a certain temperature, the metal starts to oxidize where there is 

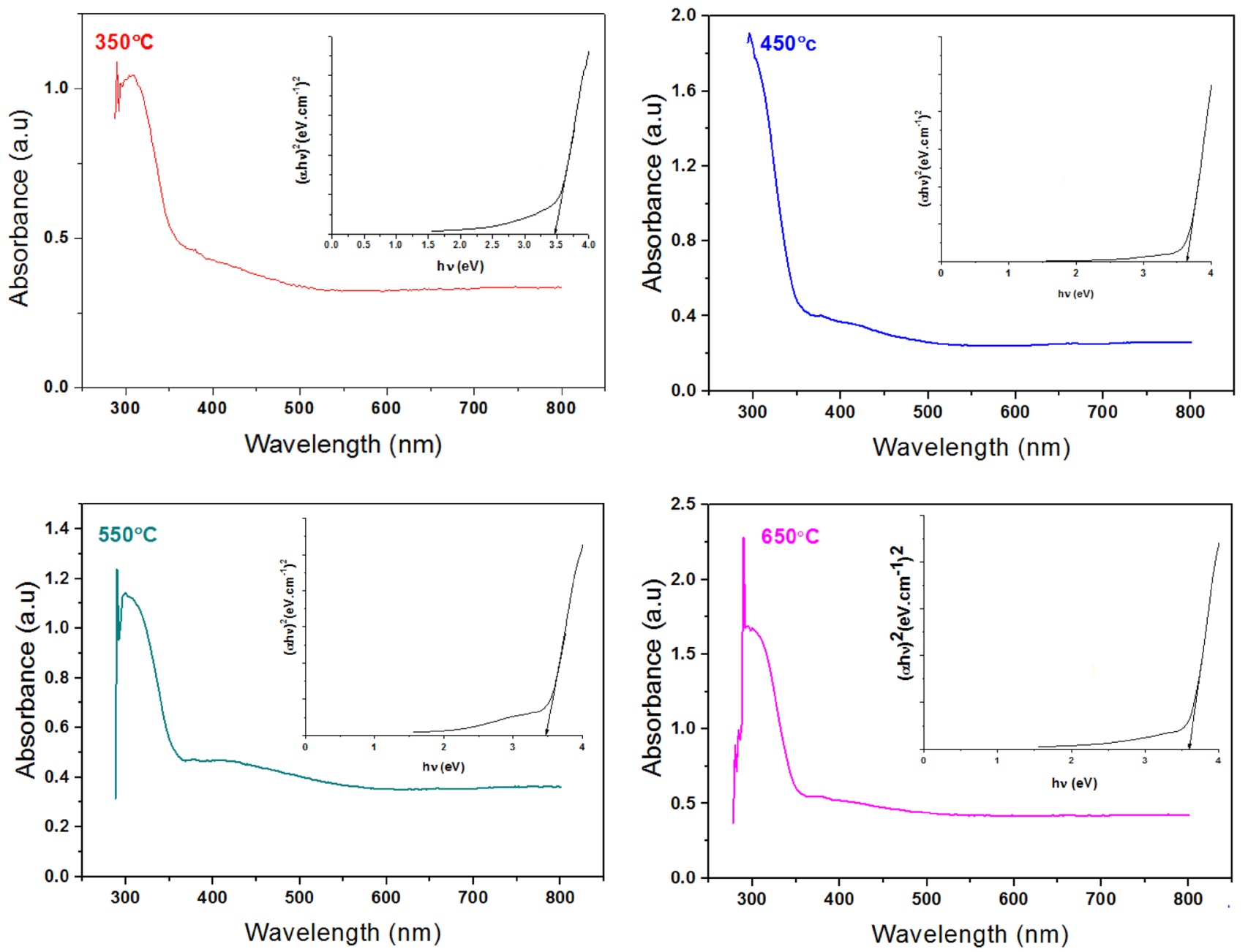

Fig. 3 Optical absorption spectra for nickel films oxidized at $350,450,550$ and $650{ }^{\circ} \mathrm{C}$. The insets show the $(\alpha h v)^{2}$ versus hv curve for the samples

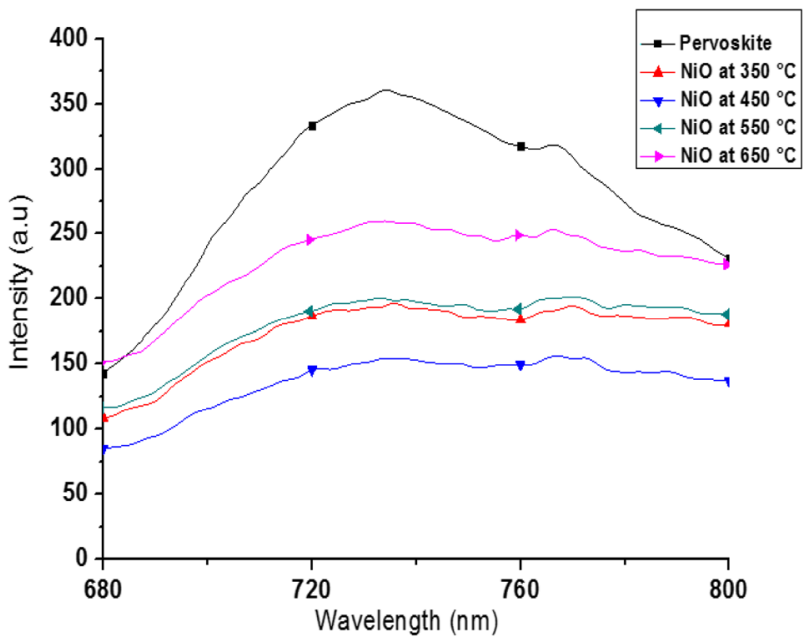

Fig. 4 PL spectra of glass/perovskite and glass/NiO/perovskite oxidized at different temperatures under an excitation wavelength of $440 \mathrm{~nm}$ chemical diffusion of oxygen ions in the crystal structure of the metal that controls the nonstoichiometric properties of the metal oxide as well as the crystal parameters of its lattice [34]. Furthermore, in the case of nickel, there are different oxidation temperatures that depend on the preparation method, the precursor of the material and the oxidation kinetics [11, 13, 15, 35]. However, the most common oxidation temperature of the nickel-metal precursor is $350{ }^{\circ} \mathrm{C}$ [35]. Figure 5 shows the X-ray diffraction patterns of $\mathrm{NiO}$ on the top of the FTO substrate at different oxidation temperatures. The pattern shows a high peak at $2 \theta=38^{\circ}$ which corresponds to the crystalline (111) plane of NiO monoclinic crystal structure as well as the formation of a weak peak at $2 \theta=62.5^{\circ}$ which corresponds to the (220) plane of $\mathrm{NiO}$. In addition, due to the rapid oxidation of nickel layer, there is a random small peak of crystalline $\mathrm{NiO}_{2}$ and $\mathrm{Ni}_{2} \mathrm{O}_{3}$ monoclinic crystal structure at $2 \theta=66.372^{\circ}$ of $(004)$ plane, and a weak peak of cubic crystal structure nickel 

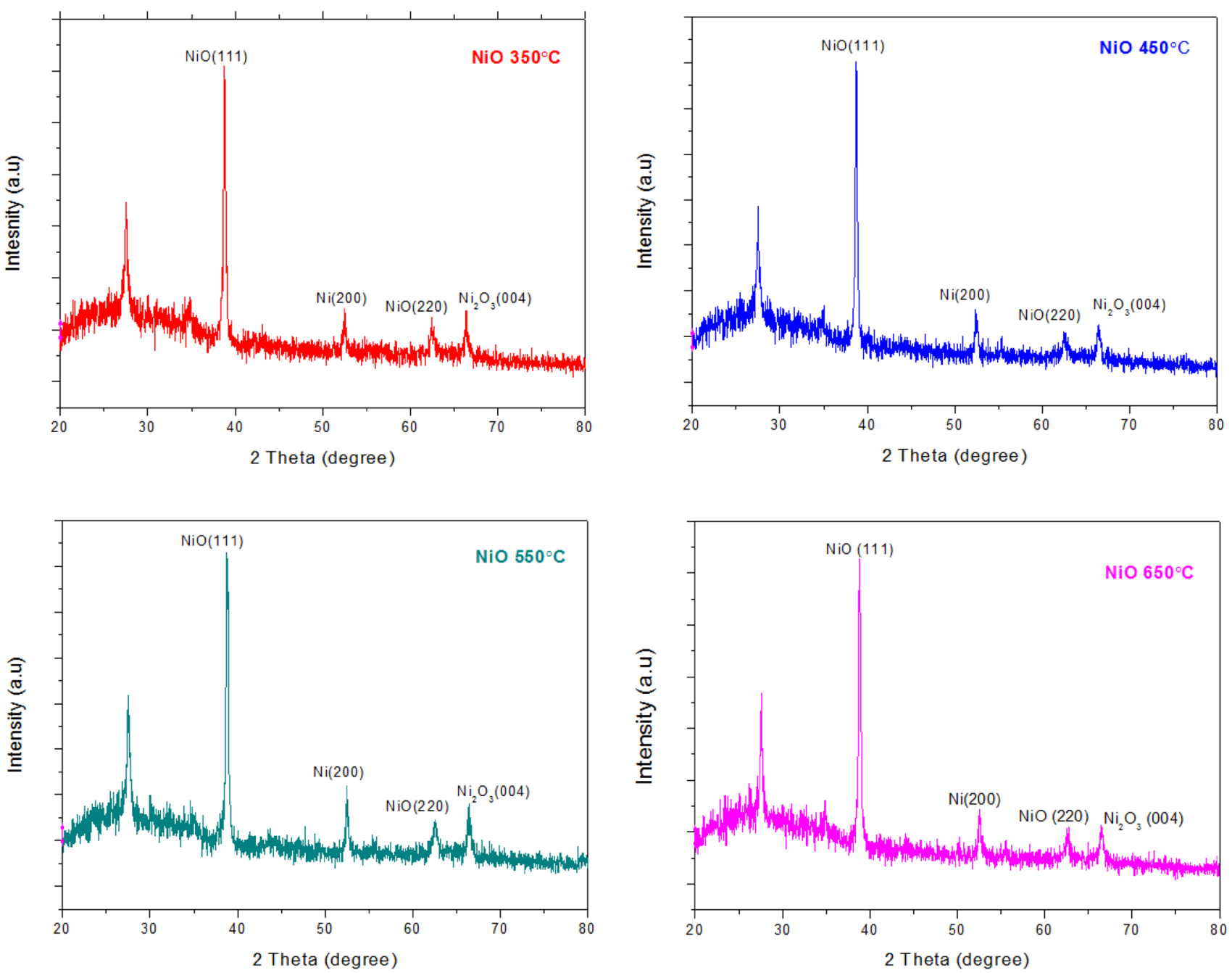

Fig. 5 XRD patterns for $\mathrm{NiO}$ films prepared on glass/FTO substrate

metal of plane (200) at $2 \theta=52.5^{\circ}$. On the other hand, at $350{ }^{\circ} \mathrm{C}$, there was an overlapping of $(-111)$ plane of $\mathrm{NiO}_{2}$ at $2 \theta=38^{\circ}$, while there was an overlapping of $(020)$ of $\mathrm{NiO}_{2}$ at $2 \theta=66.372^{\circ}$ for all oxidation temperatures. The calculated d-spacing of $\mathrm{NiO}(111), \mathrm{NiO}(220), \mathrm{Ni}_{2} \mathrm{O}_{3}(004)$, and $\mathrm{Ni}$ (200) were approximately $2.35,1.5,1.4$, and 1.7 $\mathrm{A}^{\circ}$, respectively $[36,37]$. The heat treatment of $\mathrm{Ni}$ films to form $\mathrm{NiO}$ layers revealed the incomplete incorporation of oxygen with $\mathrm{Ni}$, which was shown by the $\mathrm{Ni}$ atom signal in XRD analysis for all oxidation temperatures. This clearly shows the effect of the rapid oxidation on the composition of the film as well as the morphology of the films as seen in SEM images. The amount of crystalline phase of $\mathrm{Ni}_{2} \mathrm{O}_{3}$ indicates that $\mathrm{Ni}^{3+}$ ions formed as $\mathrm{Ni}_{2} \mathrm{O}_{3}$ phase rather than the incorporation with $\mathrm{NiO}$ matrix [38]. The crystallinity of the nickel films oxidized at different oxidation temperatures
Table 1 The crystallinity degree of the prepared $\mathrm{NiO}$ films at different oxidation temperatures

\begin{tabular}{ll}
\hline $\begin{array}{l}\text { Oxidation tem- } \\
\text { perature }\left[{ }^{\circ} \mathrm{C}\right]\end{array}$ & $\begin{array}{l}\text { Crystallinity } \\
\text { percentage }[\%]\end{array}$ \\
\hline 350 & 23.80 \\
450 & 24.70 \\
550 & 27.90 \\
650 & 25.60 \\
\hline
\end{tabular}

was investigated. Table 1 estimates the crystallinity index of the prepared $\mathrm{NiO}$ thin films.

\subsection{Morphological property of NiO layers}

Surface morphology of $\mathrm{NiO}$ layers onto the glass substrate was investigated using scanning electron microscopy as presented in Fig. 6. The surface morphology of $\mathrm{NiO}$ film at $350{ }^{\circ} \mathrm{C}$ shows no cracks due to the suitable limit 

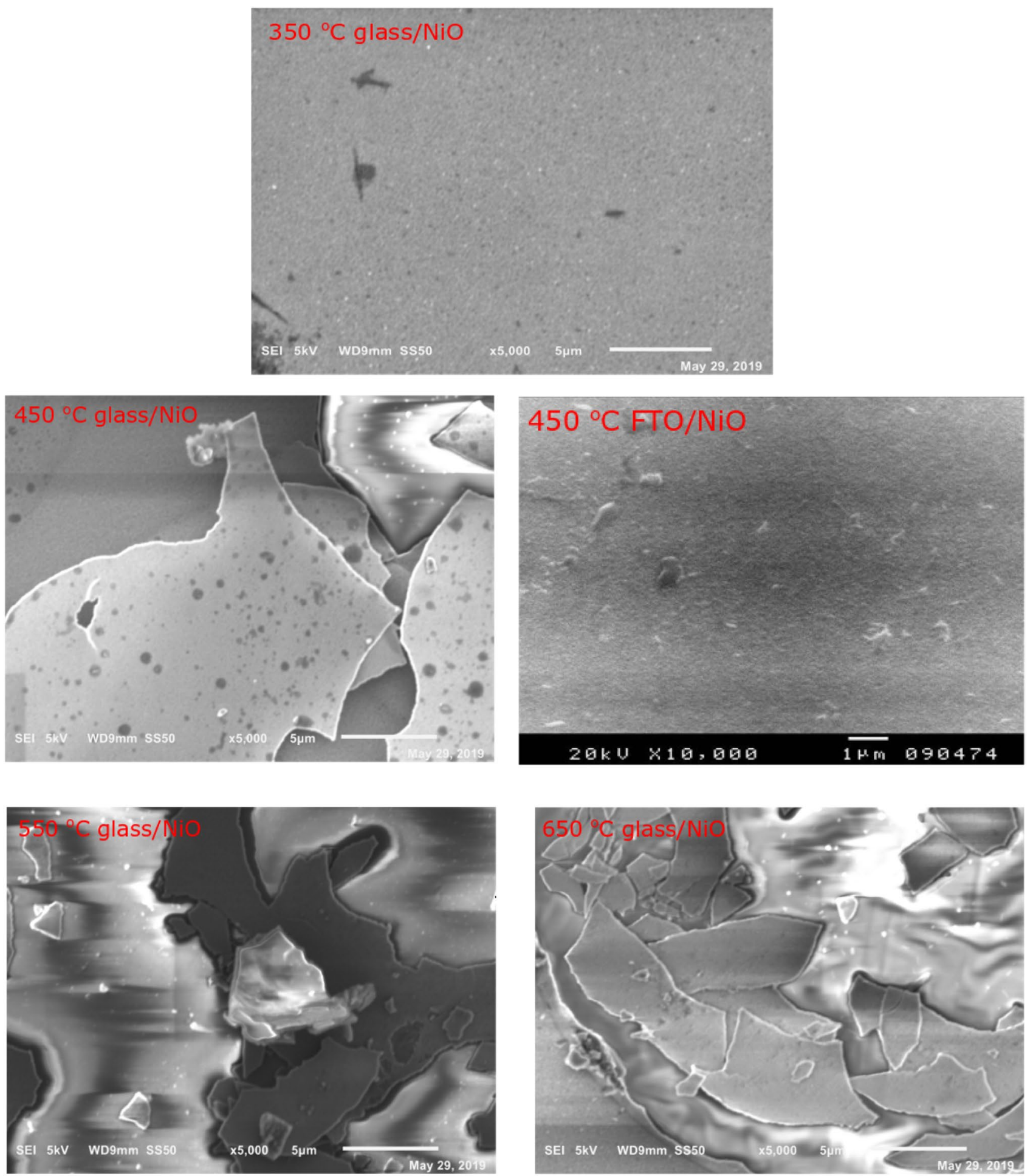

Fig. 6 SEM images of the NiO films at different oxidation temperatures

of temperature. For $\mathrm{NiO}$ film at $450{ }^{\circ} \mathrm{C}$, due to the rapid increase of the oxidation temperature, the film suffers from large cracks and pinholes along the surface of the film. Moreover, as the oxidation temperature increases in the case of 550 and $650{ }^{\circ} \mathrm{C}$, the cracks in the film's surface increase due to the high temperature. On the other hand, the surface of $\mathrm{NiO}$ layer that has been oxidized at the optimum oxidation temperature $\left(450{ }^{\circ} \mathrm{C}\right)$ has been investigated on the top of FTO to compare with the one on the glass substrate. As shown in the Fig., the film is well aligned on the 
surface of FTO due to the activity of the surface to accept the $\mathrm{NiO}$ layer. In the case of the glass substrate, the activity of the surface is low in comparison with the FTO surface that influences on the interface between $\mathrm{NiO} / \mathrm{FTO}$ bilayer. Moreover, we observed small black spots on the $\mathrm{NiO}$ sheets at $350{ }^{\circ} \mathrm{C}$, which could be related to Ni metal. However, by increasing the reaction temperature to $450-650{ }^{\circ} \mathrm{C}$, the $\mathrm{Ni}$ metals begin to grow into $\mathrm{NiO}$, forming gradually separated grains (defective or non-uniformly structure) of $\mathrm{NiO}$ layers with some uncompleted $\mathrm{Ni}-\mathrm{O}$ reaction on the sample. These unreacted $\mathrm{Ni}$ metal on $\mathrm{NiO}$ layers would increase the sample conductivity during the experiments with the formation of more electrons.

\subsection{Hall measurements}

The carrier mobility, conductivity and carrier concentrations of $\mathrm{NiO}$ thin films were measured and studied by Hall effect. Table 2 describes the relations between the oxidation temperatures and the carrier mobility, carrier concentration and conductivity. The Hall effect displays as p-type $\mathrm{NiO}$ thin films resulting from the positive sign of Hall coefficient. The values of the Hall parameters show the effect of the rapid oxidation on the formation of pinholes in the surface of the films with relative low carrier mobility and conductivity. The behaviours of the carrier mobility and conductivity are

Table 2 The carrier mobility, carrier concentrations and conductivity of $\mathrm{NiO}$ thin films vs. the oxidation temperatures

\begin{tabular}{llll}
\hline $\begin{array}{l}\text { Oxidation tem- } \\
\text { perature }\left[{ }^{\circ} \mathrm{C}\right]\end{array}$ & $\begin{array}{l}\text { Carrier mobility } \\
{\left[\mathrm{cm}^{2} / \mathrm{Vs}\right]}\end{array}$ & $\begin{array}{l}\text { Carrier concen- } \\
\text { tration }\left[\mathrm{cm}^{-3}\right]\end{array}$ & $\begin{array}{l}\text { Conductivity } \\
{\left[\Omega^{-1} \mathrm{~cm}^{-1}\right]}\end{array}$ \\
\hline 350 & $3.49 \times 10^{3}$ & $7.58 \times 10^{11}$ & $4.24 \times 10^{-4}$ \\
450 & $2.8 \times 10^{-1}$ & $1.5 \times 10^{15}$ & $6.86 \times 10^{-5}$ \\
550 & $5.57 \times 10^{-3}$ & $4.96 \times 10^{14}$ & $4.43 \times 10^{-7}$ \\
650 & $4.16 \times 10^{2}$ & $8.80 \times 10^{11}$ & $5.87 \times 10^{-5}$ \\
\hline
\end{tabular}

almost the same due to the rule of charge carriers to conduct the charge inside the film, while the behaviour of the carrier concentration is different due to the scrambling of the carriers which obstacle the flow of the carriers inside the film. The measured crystallinity indexes of the films at different oxidation temperatures showed a small fluctuation in the crystallinity degree at which the oxidized $\mathrm{Ni}$ film at $350{ }^{\circ} \mathrm{C}$ has amorphous phases higher than the oxidized film at $450{ }^{\circ} \mathrm{C}$. In addition, both films have amorphous phases higher than the oxidized films at 550 and $650{ }^{\circ} \mathrm{C}$. Consequently, these amorphous phases boost the conductivity and carrier mobility in the case of 350 and $450{ }^{\circ} \mathrm{C}$ greater than 550 and $650{ }^{\circ} \mathrm{C}$. Moreover, the defects and contaminated amount of $\mathrm{Ni}$ at low oxidation temperature increases the conductivity of the film due to their metal properties than the oxide film. The unexpected behaviour of the conductivity at the oxidation temperature of $650{ }^{\circ} \mathrm{C}$ is due to the rapid oxidation temperature that causes rapid diffusion paths of the defects during oxidation time [39]. The process in Fig. 7 shows the general oxidation process of the Ni layer, while the equivalent equation clarifies the presence of the $\mathrm{Ni}$ vacancies, electron-holes as the predominant defects in nickel oxide, as well as $\mathrm{Ni}^{2+}$ which can transform into $\mathrm{Ni}^{3+}(2 \mathrm{Ni}$ ions must be transformed for each vacancy) equivalent to the formation of $\mathrm{Ni}_{2} \mathrm{O}_{3}$ in $\mathrm{NiO}$ matrix. There is a long-standing controversy about the type of conduction in $\mathrm{NiO}$ films and the role of the defects in this process [40]. Moreover, there are extensive studies that have been performed on the bulk samples [41]; however, there are only limited studies on the oxidation kinetics of thin metal films [41]. As mentioned early, $\mathrm{NiO}$ is a p-type semiconductor with the predominant defects of cation vacancies and electron-holes [35] whose resistivity can be lowered by an increase of the hole concentration: this can be achieved by an increase of $\mathrm{Ni}^{3+}$ ions resulting from the presence of the native defects, such as nickel vacancies and/or interstitial oxygen [42]. The XRD data shows the presence of $\mathrm{Ni}^{+3}$ ions in all samples, so the possible explanation
Fig. 7 The general thermal oxidation process of the Ni layer and the equivalent equation for the formation of $\mathrm{Ni}$ vacancies and electron-holes during the oxidation process of $\mathrm{NiO}$

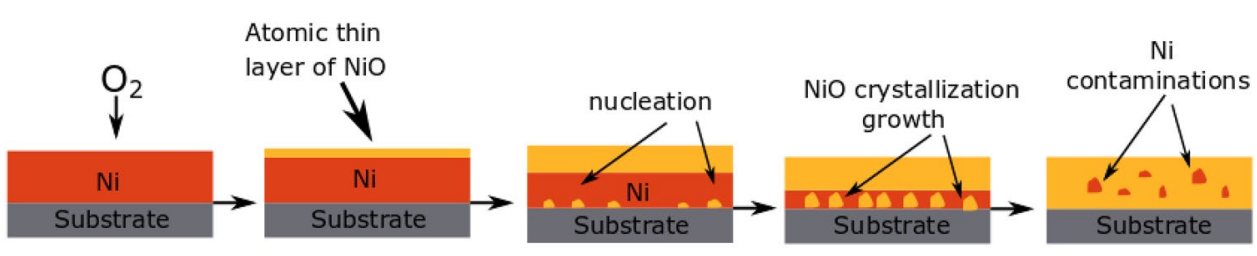

$$
\begin{aligned}
& \mathrm{Ni}^{2+} \mathrm{Ni}^{2+} \mathrm{Ni}^{2+} \mathrm{Ni}^{2+} \\
& \mathrm{Ni}^{2+} \mathrm{Ni}^{2+} \mathrm{V}_{\mathrm{Ni}}^{\prime \prime} \mathrm{Ni}^{2+} \\
& \mathrm{Ni}^{2+} \mathrm{Ni}^{2+} \mathrm{Ni}^{2+} \mathrm{Ni}^{2+} \\
& \mathrm{Ni}^{2+} \mathrm{Ni}^{2+} \mathrm{Ni}^{2+} \mathrm{Ni}^{2+} \\
& \stackrel{\mathrm{O}_{2}(\mathrm{~g})}{\longrightarrow} \begin{array}{l}
\mathrm{O}^{2-} \mathrm{Ni}^{2+} \mathrm{O}^{2-} \mathrm{Ni}^{2+} \\
\mathrm{Ni}^{2+} \mathrm{O}^{2-} \mathrm{V}_{\mathrm{Ni}}^{\prime \prime} \mathrm{O}^{2-} \\
\mathrm{O}^{2-} \mathrm{hi}^{2+} \mathrm{Ni}^{2-} \mathrm{Ni}^{2+} \\
\mathrm{Ni}^{2+} \mathrm{O}^{2-} \mathrm{Ni}^{2+} \mathrm{O}^{2-}
\end{array}
\end{aligned}
$$

Thermal oxidation process 
is the fluctuation of these ions over the oxidation process of different oxidation temperatures. Furthermore, Hwang et al. [43] considered the point defects of $\mathrm{NiO}$ as a function of temperature which confirm our explanation in this work. In that study, the coordination number of $\mathrm{Ni}-\mathrm{Ni}$ increased with increasing annealing temperature, which may be a result of the nickel vacancies greatly decreasing with increasing temperature. The temperature-dependent resistivity of $\mathrm{NiO}$ films has two paths; the changing in temperature during the oxidation process which is contributed to increasing the resistivity with increasing the oxidation temperature and increasing the annealing temperature of $\mathrm{NiO}$ films after deposition which enhance the conductivity due to the semiconductor nature of $\mathrm{NiO}$ films [42, 44, 45]. Furthermore, as reported in previous works [42, 44, 45], the electrical resistivity of $\mathrm{NiO}$ films is located between the ranges of $10-10^{6}(\Omega \mathrm{cm})$ which is the range of the electrical resistivity reported in this work. However, the very high resistivity of the $\mathrm{NiO}$ films in this work is an apparent indication of the difference between the effect of the rapid oxidation process and the handled process of $\mathrm{NiO}$ thin films.

\subsection{J-V characteristics of the fabricated perovskite solar cells}

Effect of oxidation temperature of sputtered $\mathrm{NiO}$ films as HTL on the photovoltaic performance of the fabricated $\mathrm{FTO} / \mathrm{NiO} / \mathrm{CH}_{3} \mathrm{NH}_{3} \mathrm{PbI}_{3} / \mathrm{PCBM} / \mathrm{LiF} / \mathrm{Ag}$ perovskite solar cells is investigated. The resultant $\mathrm{J}-\mathrm{V}$ curves of the PSCs with different oxidation temperature of $\mathrm{NiO}$ HTLs under the condition of AM 1.5 and Pin of $50 \mathrm{~mW} / \mathrm{cm}^{2}$ carried by Keithly power source are shown in Fig. 8. The measurements show that $\mathrm{NiO}$ film rapidly oxidized at $450{ }^{\circ} \mathrm{C}$ has the optimum photovoltaic parameters and the maximum efficiency. On optical excitation of the perovskite active layer, charge transfer from $\mathrm{CH}_{3} \mathrm{NH}_{3} \mathrm{PbI}_{3}$ into PCBM occurs where PCBM acts as an electron acceptor layer. The difference in the electron injection rate is assigned to differences in energy band alignment at the interfaces. The charge carrier recombination back to the ground state can be happened to be at least one order of magnitude faster in the $\mathrm{CH}_{3} \mathrm{NH}_{3} \mathrm{PbI}_{3} / \mathrm{PCBM}$. As explained in PL measurements, the low performance of $\mathrm{NiO}$ layers, which have been oxidized at 550 and $650{ }^{\circ} \mathrm{C}$ is due to the cracks at the surface morphology at higher temperatures that affect the extraction of the carriers at the interface. The PSCs with $\mathrm{NiO}$ HTL oxidized at $450{ }^{\circ} \mathrm{C}$ exhibit a high performance with PCE of $12.05 \%$, Jsc of $19.80 \mathrm{~mA} / \mathrm{cm}^{2}$, Voc of $0.92 \mathrm{~V}$ and $\mathrm{FF}$ of $33 \%$. Table 3 estimates the performance parameters of NiO HTLs in PSCs with a maximum power conversion efficiency of $12.05 \%$ at $450{ }^{\circ} \mathrm{C} \mathrm{NiO}$ film. Table 4 exhibits the best performance of NiO-based planar PSCs in recent years of the same main configuration $(\mathrm{NiO} /$ perovskite/ PCBM) as in this work using sputtering as the deposition technique for $\mathrm{NiO}$ and oxidized $\mathrm{Ni}$ as HTLs.
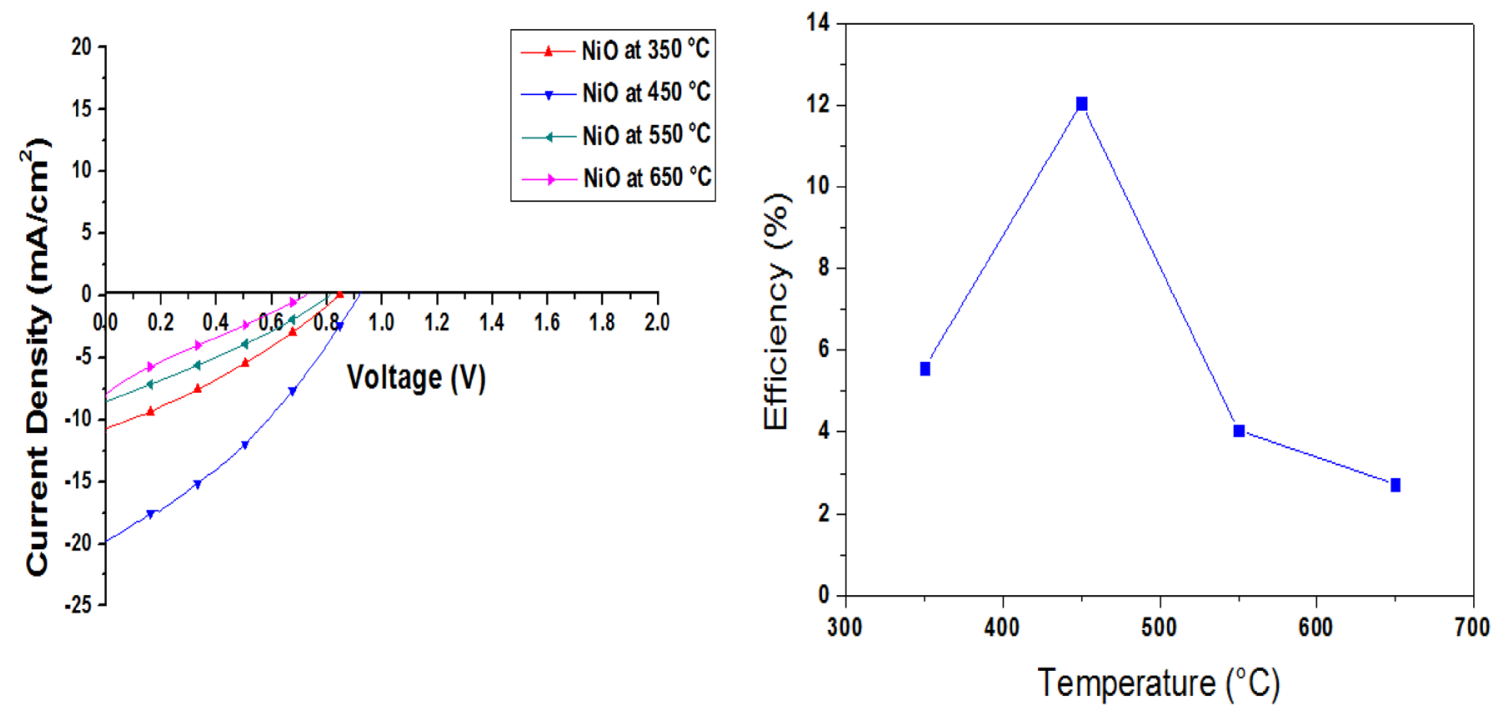

Fig. 8 J-V curves of PSCs with NiO HTL oxidized at different oxidation temperatures and the calculated efficiency vs. oxidation temperatures of sputtered Ni films 
Table 3 Photovoltaic parameters of $\mathrm{FTO} / \mathrm{NiO} /$ $\mathrm{CH}_{3} \mathrm{NH}_{3} \mathrm{PbI}_{3} / \mathrm{PCBM} / \mathrm{LiF} / \mathrm{Ag}$ at different oxidation temperatures of $\mathrm{NiO}$ films

\begin{tabular}{lllllll}
\hline $\begin{array}{l}\text { Temperature } \\
{\left[{ }^{\circ} \mathrm{C}\right]}\end{array}$ & $\mathrm{V}_{\mathrm{oc}}[\mathrm{V}]$ & $\mathrm{J}_{\mathrm{sc}}\left[\mathrm{mA} / \mathrm{cm}^{2}\right]$ & FF & PCE $[\%]$ & Area $\left[\mathrm{cm}^{2}\right]$ & $\mathrm{P}_{\text {in }}\left[\mathrm{mW} / \mathrm{cm}^{2}\right]$ \\
\hline 350 & 0.84 & 10.73 & 0.309 & 5.57 & 0.097 & 50 \\
450 & 0.92 & 19.80 & 0.331 & 12.05 & 0.194 & 50 \\
550 & 0.8 & 8.56 & 0.296 & 4.05 & 0.194 & 50 \\
650 & 0.72 & 7.97 & 0.238 & 2.73 & 0.194 & 50 \\
\hline
\end{tabular}

Table 4 Performances of the reported planar PSCs based on undoped c-NiO films as well as the performance of the $\mathrm{NiO}$ (oxidized at $450{ }^{\circ} \mathrm{C}$ ) based planar PSC in this work

\begin{tabular}{|c|c|c|c|c|c|c|c|}
\hline Device configuration & $\mathrm{V}_{\mathrm{oc}}[\mathrm{V}]$ & $\mathrm{J}_{\mathrm{sc}}\left[\mathrm{mA} / \mathrm{cm}^{2}\right]$ & FF & PCE $[\%]$ & Area $\left[\mathrm{cm}^{2}\right]$ & Method & Ref. \\
\hline $\mathrm{FTO} / \mathrm{NiO} / \mathrm{MAPbI}_{3}^{\mathrm{a}} / \mathrm{PCBM} / \mathrm{LiF} / \mathrm{Ag}$ & 0.92 & 19.80 & 0.331 & 12.05 & 0.194 & Oxidation of sputtered $\mathrm{Ni}$ & $\mathrm{CW}^{\mathrm{b}}$ \\
\hline $\mathrm{FTO} / \mathrm{NiO} / \mathrm{MAPbI}_{3} / \mathrm{PCBM} / \mathrm{Ag}$ & 1.10 & 15.17 & 0.59 & 9.84 & NA & Directly sputtered $\mathrm{NiO}$ & [46] \\
\hline $\mathrm{ITO} / \mathrm{NiO} / \mathrm{MAPbI}_{3} / \mathrm{PCBM} / \mathrm{BCP}^{\mathrm{c}} / \mathrm{Ag}$ & 0.98 & 19.69 & 0.64 & 12.4 & 0.1 & Directly sputtered NiO & [47] \\
\hline $\mathrm{FTO} / \mathrm{NiO} / \mathrm{MAPbI}_{3} / \mathrm{PCBM} / \mathrm{Au}$ & 1.03 & 23.77 & 0.54 & 13.26 & 0.07 & Directly sputtered $\mathrm{NiO}$ & [48] \\
\hline $\mathrm{FTO} / \mathrm{NiO}_{\mathrm{x}} / \mathrm{MAPbI}_{3} / \mathrm{PCBM} / \mathrm{BCP} / \mathrm{Ag}$ & 1.06 & 20.68 & 0.74 & 16.20 & 0.09 & Directly sputtered $\mathrm{NiO}$ & [49] \\
\hline
\end{tabular}

${ }^{a}$ Methylamine lead iodide

${ }^{\mathrm{b}}$ Current work

${ }^{\mathrm{c}}$ Bathocuproine

\section{Conclusion}

In conclusion, the effect of oxidation temperatures of $\mathrm{NiO}$ films as hole-transporting layers for perovskite solar cells was evaluated. From Hall measurements, there was a sharp decrease in the efficiency for temperature degrees of 550 and $650{ }^{\circ} \mathrm{C}$, which indicate that the optimum working oxidation temperature of $\mathrm{NiO}$ film is $450{ }^{\circ} \mathrm{C}$. Due to the rapid oxidation, there were low values of the conductivity, carrier mobility and carrier concentrations of the other temperature degrees. The PSCs with $\mathrm{NiO}$ oxidized at $450{ }^{\circ} \mathrm{C}$ exhibited a high performance with PCE of $12.05 \%$, Jsc of $19.80 \mathrm{~mA} /$ $\mathrm{cm}^{2}$, Voc of $0.92 \mathrm{~V}$ and $\mathrm{FF}$ of $33 \%$.

Acknowledgements Open access funding provided by University of Eastern Finland (UEF) including Kuopio University Hospital. We thank our colleagues from the Department of Advanced Materials, Institute of Central Metallurgical Research and Development, especially Professor Said El-Sheikh for assistance with Hall measurements. In addition, we would like to show our gratitude to Mohamed Samir, research assistant, IGSR, Donia Said, M.Sc, the University of Eastern Finland, and Enas Mustafa, M.Sc, Rovira I Virgili University for sharing assistance with us throughout the work.

Open Access This article is distributed under the terms of the Creative Commons Attribution 4.0 International License (http://creativeco mmons.org/licenses/by/4.0/), which permits unrestricted use, distribution, and reproduction in any medium, provided you give appropriate credit to the original author(s) and the source, provide a link to the Creative Commons license, and indicate if changes were made.

\section{References}

1. L. Calió, S. Kazim, M. Grätzel, S. Ahmad, Hole-transport materials for perovskite solar cells. Angew. Chem. Int. Ed. 55, 1452214545 (2016)

2. S. Kazim, M.K. Nazeeruddin, M. Grätzel, S. Ahmad, Perovskite as light harvester: a game changer in photovoltaics. Angew. Chem. Int. Ed. 53, 2812-2824 (2014)

3. A. Kojima, K. Teshima, Y. Shirai, T. Miyasaka, Organometal halide perovskites as visible-light sensitizers for photovoltaic cells. J. Am. Chem. Soc. 131, 6050-6051 (2009)

4. T.J. Savenije, C.S. Ponseca, L. Kunneman, M. Abdellah, K. Zheng, Y. Tian, Q. Zhu, S.E. Canton, I.G. Scheblykin, T. Pullerits, Thermally activated exciton dissociation and recombination control the carrier dynamics in organometal halide perovskite. J. Phys. Chem. Lett. 5, 2189-2194 (2014)

5. Q. Dong, Y. Fang, Y. Shao, P. Mulligan, J. Qiu, L. Cao, J. Huang, Solar cells. Electron-hole diffusion lengths $>175 \mu \mathrm{m}$ in solutiongrown $\mathrm{CH}_{3} \mathrm{NH}_{3} \mathrm{PbI}_{3}$ single crystals. Science 347, 967-970 (2015)

6. G. Magdy, M.E. Harb, A.M. Elshaer, L. Saad, S. Ebrahim, M. Soliman, Preparation of electrolytic quasi-solid-state nanofibers for dye-sensitized solar cells. JOM 71, 1944-1951 (2019)

7. M.M. Lee, J. Teuscher, T. Miyasaka, T.N. Murakami, H.J. Snaith, Efficient hybrid solar cells based on meso-superstructured organometal halide perovskites. Science 338, 643-647 (2012)

8. H.S. Kim, C.R. Lee, J.H. Im, K.B. Lee, T. Moehl, A. Marchioro, S.J. Moon, R. Humphry-Baker, J.H. Yum, J.E. Moser, Lead iodide perovskite sensitized all-solid-state submicron thin film mesoscopic solar cell with efficiency exceeding 9\%. Sci. Rep. 2, 591 (2012)

9. U. Bach, D. Lupo, P. Comte, J.E. Moser, F. Weissçrtel, J. Salbeck, H. Spreitzer, M. Grätzel, Solid-state dye-sensitized mesoporous $\mathrm{TiO}_{2}$ solar cells with high photon-to-electron conversion efficiencies. Nature 395, 583-585 (1998) 
10. J. Krgger, R. Plass, L. Cevey, M. Piccirelli, M. Grätzel, U. Bach, High efficiency solid-state photovoltaic device due to inhibition of interface charge recombination. Appl. Phys. Lett. 79, 2085-2087 (2001)

11. M.H. Li, P.S. Shen, K.C. Wang, T.F. Guo, P. Chen, Inorganic p-type contact materials for perovskite-based solar cells. J. Mater. Chem. A 3, 9011-9019 (2015)

12. W. Chen, Y. Wu, Y. Yue, W. Zhang, X. Yang, H. Chen, E. Bi, I. Ashraful, M. Grätzel, L. Han, Efficient and stable large-area perovskite solar cells with inorganic charge extraction layers. Science 350, 944-948 (2015)

13. J.R. Manders, S.W. Tsang, M.J. Hartel, T.H. Lai, S. Chen, C.M. Amb, J.R. Reynolds, F. So, Solution-processed nickel oxide hole transport layers in high efficiency polymer photovoltaic cells. Adv. Funct. Mat. 23, 2993-3001 (2013)

14. T. Abzieher, S. Moghadamzadeh, F. Schackmar, H. Eggers, F. Sutterlüti, A. Farooq, D. Kojda, K. Habicht, R. Schmager, A. Mertens, R. Azmi, L. Klohr, J.A. Schwenzer, M. Hetterich, U. Lemmer, B.S. Richards, M. Powalla, U.W. Paetzold, Electronbeam-evaporated nickel oxide hole transport layers for perovskitebased photovoltaics. Adv. Energy Mater. 9, 1802995 (2019)

15. J. Cui, F. Meng, H. Zhang, K. Cao, H. Yuan, Y. Cheng, F. Huang, M. Wang, $\mathrm{CH}_{3} \mathrm{NH}_{3} \mathrm{PbI}_{3}$-based planar solar cells with magnetronsputtered nickel oxide. ACS Appl. Mater. Interfaces 6, 22862-22870 (2014)

16. W.C. Lai, K.W. Lin, T.F. Guo, J. Lee, Perovskite-based solar cells with nickel-oxidized nickel oxide hole transfer layer. IEEE Trans. Electron Devices 62, 1590-1595 (2015)

17. C.H. Yang, S.C. Lee, S.C. Chen, T.C. Lin, The effect of annealing treatment on microstructure and properties of indium tin oxides films. Mater. Sci. Eng. B 129, 154-160 (2006)

18. F. Li, C. Chen, F. Tan, C. Li, G. Yue, L. Shen, W. Zhang, Semitransparent inverted polymer solar cells employing a sol-gelderived $\mathrm{TiO}_{2}$ electron-selective layer on FTO and $\mathrm{MoO}_{3} / \mathrm{Ag} /$ $\mathrm{MoO}_{3}$ transparent electrode. Nanoscale Res. Lett. 9, 579 (2014)

19. J.H. Im, C.R. Lee, J.W. Lee, S.W. Park, N.G. Park, $6.5 \%$ efficient perovskite quantum-dot-sensitized solar cell. Nanoscale $\mathbf{3}$, 4088-4093 (2011)

20. M. Konstantakou, D. Perganti, P. Falaras, T. Stergiopoulos, Antisolvent crystallization strategies for highly efficient perovskite solar cells. Crystals 7, 291 (2017)

21. V. More, V. Shivade, P. Bhargava, Effect of cleaning process of substrate on the efficiency of the DSSC. Trans. Indian Ceram. Soc. 75, 59-62 (2016)

22. N.J. Jeon, J.H. Noh, Y.C. Kim, W.S. Yang, S. Ryu, S. Il Seok, Solvent engineering for high-performance inorganic-organic hybrid perovskite solar cells. Nat. Mater. 13, 897-903 (2014)

23. K. Lee, J. Ryu, H. Yu, J. Yun, J. Lee, J. Jang, Enhanced efficiency and air-stability of $\mathrm{NiO}_{X}$-based perovskite solar cells via PCBM electron transport layer modification with triton X-100. Nanoscale 9, 16249-16255 (2017)

24. N.M. Schmerl, J.S. Quinton, G.G. Andersson, On the growth of evaporated LiF on P3HT and PCBM. J. Phys. Chem. C 122, 23420-23431 (2018)

25. E.J.J. Pérez, M. Wussler, F.F. Santiago, K.L. Wollny, E. Mankel, T. Mayer, W. Jaegermann, I.M. Sero, Role of the selective contacts in the performance of lead halide perovskite solar cells. J. Phys. Chem. Lett. 5, 680-685 (2014)

26. Z. Song, S.C. Watthage, A.B. Phillips, M.J. Heben, Pathways toward high-performance perovskite solar cells: review of recent advances in organo-metal halide perovskites for photovoltaic applications. J. Photonics Energy 6, 022001 (2016)

27. S.S. Malia, C.K. Hong, p-i-n/n-i-p type planar hybrid structure of highly efficient perovskite solar cells towards improved air stability: synthetic strategies and the role of p-type hole transport layer (HTL) and n-type electron transport layer (ETL) metal oxides. Nanoscale 8, 10528-10540 (2016)

28. E. Li, Y. Guo, T. Liu, W. Hu, N. Wang, H. He, H. Lin, Preheatingassisted deposition of solution-processed perovskite layer for an efficiency-improved inverted planar composite heterojunction solar cell. RSC Adv. 6, 30978-30985 (2016)

29. J. Zhang, F. Li, K. Yang, C.P. Veeramalai, T. Guo, Low temperature processed planar heterojunction perovskite solar cells employing silver nanowires as top electrode. Appl. Surf. Sci. 369, 308-313 (2016)

30. M. Sreemany, S. Sen, A simple spectrophotometric method for determination of the optical constants and band gap energy of multiple layer $\mathrm{TiO}_{2}$ thin films. Mater. Chem. Phys. 83, 169-177 (2004)

31. A. Venter, J.R. Botha, Optical and electrical properties of $\mathrm{NiO}$ for possible dielectric applications. S. Afr. J. Sci. 107, 1-2 (2011)

32. J. Tauc, Optical properties and electronic structure of amorphous Ge and Si. Mater. Res. Bull. 3, 37-46 (1968)

33. S. Hietzschold, S. Hillebrandt, F. Ullrich, J. Bombsch, V. Rohnacher, S. Ma, W. Liu, A. Köhn, W. Jaegermann, A. Pucci, W. Kowalsky, E. Mankel, S. Beck, R. Lovrincic, Functionalized nickel oxide hole contact layers: work function versus conductivity. ACS Appl. Mater. Interfaces 9, 39821-39829 (2017)

34. A. Jayendran, Englisch für maschinenbauer, 2nd edn. (Springer, Germany, 1997), pp. 43-49

35. S. Mrowec, Z. Grzesik, Oxidation of nickel and transport properties of nickel oxide. J. Phys. Chem. Solids 65, 1651-1657 (2004)

36. L.D.L.S. Valladares, A. Ionescu, S. Holmes, C.H.W. Barnes, A.B. Domínguez, O.A. Quispe, J.C. González, S. Milana, M. Barbone, A.C. Ferrari, H. Ramos, Y. Majima, Characterization of Ni thin films following thermal oxidation in air. J. Vac. Sci. Technol. 32, 051808 (2014)

37. U. Kwon, B.G. Kim, D.C. Nguyen, J.H. Park, N.Y. Ha, S.J. Kim, S.H. Ko, S. Lee, D. Lee, H.J. Park, Solution-processible crystalline $\mathrm{NiO}$ nanoparticles for high-performance planar perovskite photovoltaic cells. Sci. Rep. 6, 30759 (2016)

38. N. Srivastava, P.C. Srivastava, Realizing NiO nanocrystals from a simple chemical method. Bull. Mater. 33, 653-656 (2010)

39. R. Haugsrud, On the high-temperature oxidation of nickel. Corros. Sci. 45, 211-235 (2003)

40. P. Lunkenheimer, A. Loidl, C.R. Ottermann, K. Bange, Correlated barrier hopping in NiO films. Phys. Rev. B 44, 5927 (1991)

41. Y. Unutulmazsoy, R. Merkle, D. Fischer, J. Mannhart, J. Maier, The oxidation kinetics of thin nickel films between 250 and 500 ${ }^{\circ}$ C. Phys. Chem. Chem. Phys. 19, 9045-9052 (2017)

42. H. Sato, T. Minami, S. Takato, T. Yamada, Transparent conducting p-type $\mathrm{NiO}$ thin films prepared by magnetron sputtering. Thin Solid Films 236, 27-31 (1993)

43. W.L. Jang, Y.M. Lu, W.S. Hwang, T.L. Hsiung, H.P. Wang, Point defects in sputtered NiO films. Appl. Phys. Lett. 94, 062103 (2009)

44. A.J. Varkey, A.F. Fort, Solution growth technique for deposition of nickel oxide thin films. Thin Solid Films 235, 47-50 (1993)

45. D. Adler, L.H. Tjeng, F.C. Voogt, T. Hibma, G.A. Sawatzky, C.T. Chen, J. Vogel, M. Sacchi, S. Iacobucci, Temperature and thickness dependence of magnetic moments in $\mathrm{NiO}$ epitaxial films. Phys. Rev. B 57, 11623 (1998)

46. J. Cui, F.P. Meng, H. Zhang, K. Cao, H.L. Yuan, Y.B. Cheng, F. Huang, M.K. Wang, CH3NH3PbI3-based planar solar cells with magnetron-sputtered nickel oxide. ACS Appl. Mater. Interfaces 6, 22862-22870 (2014) 
47. H. Lee, Y.T. Huang, M.W. Horn, S.P. Feng, Engineered optical and electrical performance of $\mathrm{rf}$-sputtered undoped nickel oxide thin films for inverted perovskite solar cells. Sci. Rep. 8, 5590 (2018)

48. P. Yang, J. Wang, X. Zhao, J. Wang, Z. Hu, Q. Huang, L. Yang, Magnetron-sputtered nickel oxide films as hole transport layer for planar heterojunction perovskite solar cells. Appl. Phys. A 125, 481 (2019)
49. X. Yan, J. Zheng, L. Zheng, G. Lin, H. Lin, G. Chen, B. Du, F. Zhang, Optimization of sputtering $\mathrm{NiO}_{\mathrm{x}}$ films for perovskite solar cell applications. Mater. Res. Bull. 103, 150-157 (2018)

Publisher's Note Springer Nature remains neutral with regard to jurisdictional claims in published maps and institutional affiliations. 